\title{
Nutrition status and inequality among children in different geographical regions of Maharashtra, India
}

\author{
Rushikesh P. Khadse ${ }^{\text {a }}$, Himanshu Chaurasia ${ }^{\text {b** }}$ \\ ${ }^{a}$ International Institute for Population Sciences, Govandi Station Road, Deonar, Mumbai, 400088, India \\ ${ }^{\mathrm{b}}$ National Institute for Research in Reproductive Health, ICMR, Parel, Mumbai, India
}

\section{A R T I C L E I N F O}

\section{Keywords:}

Malnutrition

Biological

Environmental

Cultural

Inequality

Geographical regions

Decomposition

Lack of development

Poor awareness

\begin{abstract}
A B S T R A C T
Introduction: Nutritional status is influenced by the complex social, biological, environmental and cultural factors that are highly interrelated. Despite being a demographically and economically developed state, Maharashtra has a high prevalence rate of child malnutrition with alarming figures. There is uneven development in different geographical regions.

Aim: This paper assesses the extent of nutritional status and inequalities among children in different regions of Maharashtra.

Data and Methods: This study utilizes data from the fourth Round of the National Family Health Survey (2015-16), the large-scale survey on demography and health recently conducted. Simple chi-square test was conducted to test the association and, further binary logistic regression analysis was done by adjusting various socio-economic and demographic characteristics. Additionally, to deal with the inequality aspect, concentration curve, concentration index, and decomposition analysis techniques were used to access and measure the degree of socio-economic inequality in geographical regions of Maharashtra.

Results: The result shows that household aspect wealth quintile, religion caste/tribe, mother education, child ever born and different regions of Maharashtra were the main factors contributing to poor child malnutrition. Rural area has the highest percentage of underweight (40\%) children followed by stunted (38\%) and wasted (26\%) respectively. Almost half of the children are underweight whose mother has no education, with $45 \%$ of stunted and $26 \%$ wasted children. Nandurbar district of North-Maharashtra regions has a prevalence of underweight (56.17 per 100) and stunted (47.38 per 100) children while Gadchiroli district of Vidarbha region has highest prevalence of wasted (46.59 per 100) children respectively.

Discussion: Due to lack of proper development, poor awareness about keeping up and improving the dietary benefit of nourishment and absence of cleanliness and sanitation as compared with other social groups.

Conclusions: The aim of this paper was to explore the geographical variations in malnutrition in Maharashtra. The present study plentifully uncovers that, as far as child nutrition is concerned, the Scheduled Tribes groups seems to be socially excluded among all the social classes. Economic growth has played a definite role in reducing child nutrition, but it is not primarily responsible for the significant decline. As per the results, we have seen that among rich and poor inequalities exists and were highly significantly different regions of Maharashtra. Recommadations: The paper calls for state and regions specific strategies which are needed to be designed and executed on a priority basis, keeping in view the keeping in view the idea of disparity or the nature of inequality in childhood malnutrition in the state and its differential characteristics across the regions.
\end{abstract}

\section{Introduction}

Globally, out of the total children aged under-five years, almost 165 million were stunted (height for age) and 52 million were wasted (weight for height). The prevalence of underweight has decreased from $26.5 \%$ to $17.6 \%$ in $1990-2015$. $^{1}$ The United Nations International
Children's Emergency Fund (UNICEF) world-level estimates for wasting was $7.5 \%$. Malnutrition is a major cause of child mortality and widely recognized as a public health problem in developing countries including India. India has a very high burden of childhood stunting as 61 million (37\%) of the 165 million stunted children aged under five years globally are Indian children. ${ }^{2}$ Approximately $43 \%$ of children are

\footnotetext{
* Corresponding author.

E-mail addresses: rushikeshkhadse@gmail.com (R.P. Khadse), himanshu.icmr369@gmail.com (H. Chaurasia).
} 
underweight (weight for age), one out of every five children is wasted, and almost half of the children are stunted (UNICEF. ${ }^{3}$ Under the Millennium Development Goal -1 (MDG-1), one of the key indicators was to reduce the proportion of malnourished children through the reduction in poverty and hunger and to halve the prevalence of underweight children by 2015. Goal 2 of Sustainable Development Goals (SDGs) aimed to end hunger and all forms of malnutrition by 2030. Nearly, almost half of all deaths in children of age under- 5 are attributable to undernutrition, turning into an unnecessary loss of around 3 million young lives worldwide every year. ${ }^{4}$

Various factors are responsible for malnutrition; different authors have addressed the issues of Malnutrition of Children. ${ }^{5}$ found that the proportion of children having low birth weight are at higher risk among women who are not educated. Nutrition status has found to be positively associated with infant feeding practices. It is found that children who take exclusive breastfeeding fewer chance of malnutrition. ${ }^{6}$ The optimal use of nutritious food feeding is healthy for child growth and development. ${ }^{7}$ Infectious diseases like diarrhea, pneumonia, and measles increase the risk of mortality among those children who are stunted, underweight and wasted children. ${ }^{8,9}$ Practices of personal hygiene and sanitation are fundamental to avoid stunting among children and are useful for the growth and development of children (Rah et al., 2015). The prevalence of malnutrition was found to be high among the tribal population due to their poor condition. Parents are working in agriculture, and non-agricultural area similarly who are below the poverty line and having Antyodya card and no schooling these are factor leads to high malnutrition among the children. ${ }^{10}$ Evidence suggests that the level of stunted children has declined from $52 \%$ in $1992-93$ to $38 \%$ by $2015-16$ but the prevalence of wasted had increased from $17 \%$ to $28 \%$ during this period as reported in National Family Health Survey (NFHS 4). Moreover, in 2016, India accounted for 62 million stunted children, $40 \%$ of the global share of stunting in Maharashtra (UNICEF. ${ }^{3}$ The trends in malnutrition prevalence in Maharashtra from 2005 to 2016 by different rounds of NFHS surveys are shown in Fig. 1.

With this background, we decided to conduct a study to compare the prevalence of malnutrition in different geographical regions of Maharashtra and what socio-demographic and economic factors are responsible for it. The current study also aims to explain the factors contributing to the poor/non-poor gap in child malnutrition in Maharashtra. The gap between poor and non-poor and the contributing factors that clarify this gap in childhood malnutrition is most glaring in comparative and nationally representative and may support policymakers in their endeavors to diminish this gap. Very few studies have emphasized the mounting poor/non-poor gap in childhood undernutrition in different countries including India. ${ }^{11,12}$ To our knowledge, there exists no available literature explaining the poor/non-poor gap in child malnutrition in Maharashtra.

\section{Data source and methods}

Indian Demographic Health Survey commonly known as the National Family Health Survey (NFHS-4) is the Round-IV conducted during 2015-16. The Round-I in 1992-93, Round-II in 1998-99, and

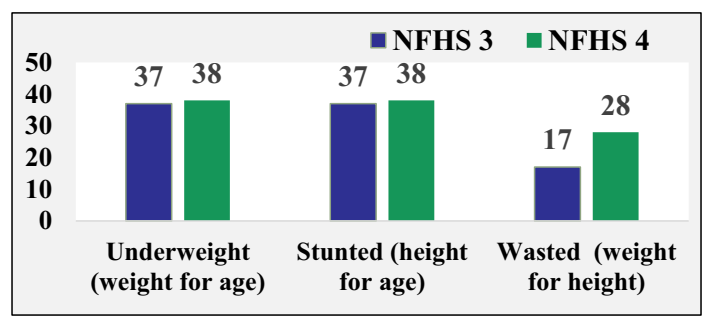

Fig. 1. Prevalence of malnutrition in Maharashtra from 2005 to 2016 (NFHS).
Round-III in 2005-2006 were conducted. The Ministry of health and family welfare (MoHFW), Government of India had designated the International Institute for Population Sciences (IIPS), Mumbai as the nodal agency for conducting the survey. NFHS-4 data for the first time provide district-level estimates of important indicators on population, health, nutrition, fertility and mortality for India and each State/Union territory. It provides data on 601,509 households (response rate $=98 \%$ ), 103,525 men (response rate $=92 \%$ ), and 699,686 women (response rate $=97 \%$ ) who were successfully interviewed. Multistage stratified sampling design was adopted and the 2011 census census served as the sampling frame for the selection of Primary Sampling Units (PSUs) for rural and urban areas. Villages in rural areas and Census Enumeration Blocks (CEBs) for urban areas were selected as PSUs from the sampling frame in the survey. Probability proportional to size (PPS) sampling were used to select the final sample PSUs. The detailed sampling technique adopted by the survey has been described elsewhere. ${ }^{13}$ Three indices were used to measure the nutritional status of children which is used as a dependent variable, and these indices are Height for age (Stunting), Weight for height (Wasting), and Weight for age (Underweight). In the present study, $\mathrm{Z}$ scores were used to access the status of malnourishment. The values of the $\mathrm{Z}$ scores were dichotomized and denoted and used as the binary response for Stunting, wasted, and underweight. Several socio-economic and demographic variables such as the age of mother, age at first birth, birth order, caste, districts of the state, education, marital status, media exposure, place of residence, religion, sex of the child, and wealth quintiles were included as the predictor variables in the study.

A chi-squared test is often used to determine whether there is a significant association between the observed frequencies and the expected frequencies in one or more categories, denoted by $\chi^{2}$ and described as:

$\chi^{2}=\sum(x i-m i)^{2} / m i, x i($ for $i=1,2 \ldots \ldots . K)$

Binary logistic regression analysis is applied to obtain the odds of children having stunting, wasting and underweight before completing five years of life. The dependent variable in the model is stunting, wasting and underweight, maximum likelihood function commonly estimates beta regression coefficients. For these outcome variables, Logistic regression model takes the form:

$\log \frac{p}{(1-p)}=\beta_{0}+\beta_{1} x_{1}+\beta_{2} x_{2}+\beta_{3} \ldots \ldots \ldots \beta_{n} x_{n}$

where Xi's are covariates and ifs are coefficients. $\mathrm{P}$ is predicted probability, and $\log$ odds $\mathrm{P}$ and (1-P) provides the odds ratios with respects to the reference category.

Additionally, to deal with the inequality aspect, concentration curve, concentration index, and decomposition analysis techniques were used to measure the degree of socio-economic inequality. This technique is useful in explaining the gap in outcome between the two population groups. Concentration curve examines whether inequality exists in one group or not, but it fails to estimate the magnitude of inequality. Therefore, the concentration index is used to measure the degree of socio-economic inequality.

Concentration index value lies between -1 and 1 . A negative value means the disproportionate concentration among the poor group while a positive value indicates the concentration exists among the rich group. ${ }^{14,15}$ A zero concentration index value indicates that there is no socio-economic inequality.

$\mathrm{C}=\frac{2}{\mu} \operatorname{cov}_{\mathrm{w}}\left(\mathrm{y}_{\mathrm{i}} \mathrm{r}_{\mathrm{i}}\right)$

where $y_{i}$ and $r_{i}$ are the health status of the ith individual and the fractional rank of the ith individual; $\mu$ is the (weighted) mean of the health variable in the sample, and $\operatorname{cov}_{\mathrm{w}}$ denotes the weighted covariance respectively. ${ }^{16,17}$

Decomposition Analysis Wagstaff and colleagues (1991) proposed a 
method to decompose the socio-economic inequality which had an advantage over linear and non-linear regression models. ${ }^{15}$ It allows one to estimate the relative contribution of factors to inequality in a health variable (e.g., the gap between poor and rich). For a linear additive regression model

$Y_{i}=\alpha+\sum_{k}^{0} \beta_{k} X_{k i}+\varepsilon_{i}$

where $\alpha$ is the intercept, $X_{k i}$ is the relative contribution of factors and $\varepsilon_{i}$ is the residual error term. Based on the above equation, the concentration index $Y_{i}, C$, can be written as

$C=\sum_{k}^{0}\left(\frac{\beta_{k} \overline{\mathrm{X}}_{k}}{\mu}\right) C_{k}+\frac{G C_{\varepsilon}}{\mu}$

where $\beta_{k}=$ denotes the regression coefficient of determinant $\mathrm{k}$, $\overline{\mathrm{X}}_{\mathrm{k}}=$ the mean of the determinant $\mathrm{k}$,

$\mu$ the mean of malnutrition index,

$C_{k}=$ the concentration index for determinant $\mathrm{k}$, and

$G C \varepsilon=$ denotes the generalized concentration index for the error term.

The above equation shows that overall inequality, and it has two components, i.e., deterministic or "explained" and "unexplained." The explained component equals to a weighted sum of the concentration indices of the regressors, where the weights are simply the elasticities, i.e. the percentage change in the dependent variable is associated with a percentage change in the explanatory variable. However, the unexplained component reflects inequality across socio-economic groups which can't be explained by the selected predictors. ${ }^{18}$

\section{Results}

Fig. 2 shows the malnutrition status among the children in different geographical regions of Maharashtra. Underweight is the highest among the North-Maharashtra with $38.9 \%$ and lowest in West-Maharashtra with $20.4 \%$ followed by Vidharbha, Marathwada, Konkan respectively. North-Maharashtra has the highest wasted children with $34.6 \%$ and lowest with 17.8 in the geographical region of West-Maharashtra. Marathwada has the highest stunting children with $45.7 \%$ and lowest with $22.3 \%$ in West-Maharashtra followed by Vidharbha, North-Maharashtra, and Konkan respectively. The districts wise prevalence with its ranking from highest to lowest for underweight, stunted and wasted is shown in Table A (appendix).

Table 1 shows the percentage distribution of child malnutrition and its association with different background characteristics. Rural area has $40 \%$ underweight children with $38 \%$ of stunted children and only $26 \%$ wasted children approximately, showing significant association. As the number of children ever born to women increases, the percent of underweight and stunted children also increases, while wasted decreases. Almost half of the children are underweight whose mothers have not educated. Mothers with no education have $45 \%$ of stunted children,

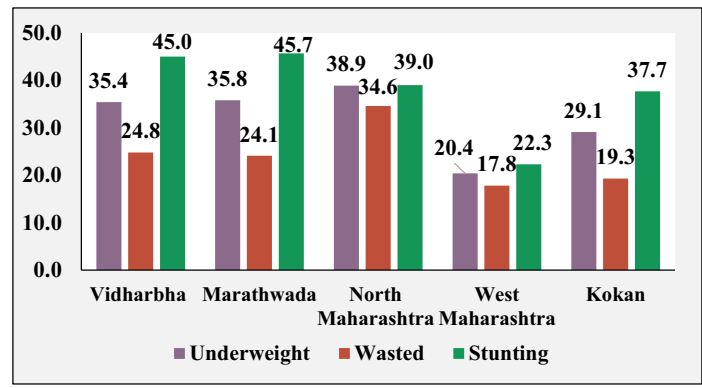

Fig. 2. Nutritional status of children in different regions of Maharashtra.
$26 \%$ of wasted children showing significant association respectively. Approximately $37 \%$ of children are underweight among Hindu and Buddhist, $44 \%$ of stunted children are among Buddhist, and $27 \%$ of children are wasted among Hindu. Mothers who belong to ST caste have a higher percentage of underweight, stunted, and wasted children compared to other castes. The overall percentage of underweight, stunted, and wasted children is high among the poorest mothers. NorthMaharashtra region has the highest underweight (40\%) and wasted (30.45\%) children respectively. Marathwada region has the highest (40\%) of stunted children. Mothers caste, wealth status and regions are significantly associated with underweight, stunted and wasted children.

Table 2 shows the adjusted odds ratio of underweight children concerning several background characteristics. Model 1 shows the household background characteristics after adjusting mother and child background characteristics; model 2 shows the household and mother background characteristic and model 3 consider the full background variables. The odds of children are less likely to be underweight as we move from poorest to richest showing statistically significant result in all the three models. In Model 1 children belong to ST category are more likely to be underweight ( $\mathrm{aO} . \mathrm{R}=1.26$; $\mathrm{C} \cdot \mathrm{I} ; 1.03-1.53$ ) showing is statistically significant as compared to others category, while in model 2 and model 3 children are more likely to be underweight but the findings are not statistically significant. In model 1, north Maharashtra region children are more likely to be underweight, while in West Maharashtra region, the children are less likely to be underweight with statistically significant compared to other region. In model 2 and model 3 , children are less likely to be underweight in other regions with Marathwada, West Maharashtra, and Konkan regions showing significant results when compared to Vidharbha region. Mothers with primary education are likely to be underweight while higher educated mothers are less likely with significant result compared to mothers with no education. The odds ratio of children having BMI 18.5-24.9 and BMI greater than 25 are less likely to be underweight with significant results in both model 2 and model 3 respectively. Women who breastfeed their children are less likely to be underweight.

Table 3 shows the adjusted odds ratio of stunted children by background characteristics. Model 1 shows the household background characteristic after adjusting mother and child background characteristics. In model 1, the odds of children are less likely to be stunted with significant findings among all the wealth categories while the findings were significant among richer and richest category in model 2 and model 3. The odds of stunted children in Muslim is 1.09 times in model $1,1.02$ in model 2 and model 3, times higher than children who are Hindu. In model 1 (aO.R = 1.17, C.I: 0.95-1.44), in model 2 and model 3 , the stunted children have odds ratio of 1.24 times in Buddhist, compared to Hindus showing significant results. Children who belongs to OBC and other category are less likely to have stunted children with significant findings in all the three models. In West Maharashtra, in model 1 , the odds is less likely (aO.R $=0.62$ ) to have stunted children, with 0.6 odds ratio in model 2 and model 3 respectively. Mothers with higher education have aO.R $=0.67$, i.e., less likely to have stunted children with significant p value in model 2 and model 3 . The result shows that in model 2 and model 3, children whose BMI were $>25.0$ were less likely to be stunted compared to those whose BMI were $<$ 18.5. A significant relationship is observed between stunted children and BMI. It is observed that children whose age is between 13 and 23 months were more likely to be stunted compare to those children age less than 13 months with statistically significant results. Women who breastfeed their children are less likely to be stunted.

Table 4 shows the adjusted odds ratio of wasted children concerning several background characteristics. The odds of children are less likely to be wasted as we move from poorer to richest with significant result in poorer when compared to poorest in model 1 . North Maharashtra region are more likely to have wasted children compared to Vidharbha region while other regions are less likely. In model 1, Marathwada and West Maharashtra have shown significant results after adjusting mother 
Table 1

distribution and factors associated with malnutrition among children (0-59 months) by background characteristics, Maharashtra, India, NFHS-4.

\begin{tabular}{|c|c|c|c|c|c|c|}
\hline & \multicolumn{2}{|c|}{ Underweight } & \multicolumn{2}{|c|}{ Stunted } & \multicolumn{2}{|c|}{ Wasted } \\
\hline & No & Yes & No & Yes & No & Yes \\
\hline Age of Mother & \multicolumn{2}{|c|}{$\chi^{2}=1.7552$} & \multicolumn{2}{|c|}{$\chi^{2}=1.3659$} & \multicolumn{2}{|c|}{$\chi^{2}=0.9141$} \\
\hline$<24$ & 63.83 & 36.17 & 65.42 & 34.58 & 74.15 & 25.85 \\
\hline $25-34$ & 64.38 & 35.62 & 66.03 & 33.97 & 75.27 & 24.73 \\
\hline$>34$ & 63.15 & 36.85 & 65.75 & 34.25 & 68.74 & 31.26 \\
\hline Child Ever Born & \multicolumn{2}{|c|}{$\chi^{2}=75.9245^{* * *}$} & \multicolumn{2}{|c|}{$\chi^{2}=60.4491^{* * *}$} & \multicolumn{2}{|c|}{$\chi^{2}=6.0818$} \\
\hline 1 & 68 & 32 & 68.04 & 31.96 & 74.08 & 25.92 \\
\hline 2 & 65.5 & 34.5 & 67.53 & 32.47 & 74.84 & 25.16 \\
\hline 3 & 62.33 & 37.67 & 64.91 & 35.09 & 75.5 & 24.5 \\
\hline $4+$ & 48.61 & 51.39 & 51.62 & 48.38 & 71.69 & 28.31 \\
\hline ANC & \multicolumn{2}{|c|}{$\chi^{2}=14.2916^{* * *}$} & \multicolumn{2}{|c|}{$\chi^{2}=18.762^{* * *}$} & \multicolumn{2}{|c|}{$\chi^{2}=0.30$} \\
\hline No $\mathrm{ANC}^{\circledast}$ & 61.15 & 38.85 & 62.18 & 37.82 & 74.82 & 25.18 \\
\hline Full ANC & 65.4 & 34.6 & 67.01 & 32.99 & 74.82 & 25.18 \\
\hline BMI & \multicolumn{2}{|c|}{$\chi^{2}=167.7635^{* * *}$} & \multicolumn{2}{|c|}{$\chi^{2}=58.0017^{* * *}$} & \multicolumn{2}{|c|}{$\chi^{2}=67.4123^{* * *}$} \\
\hline$<18.5^{\circledast}$ & 53.35 & 46.65 & 58.88 & 41.12 & 70.02 & 29.98 \\
\hline $18.5-24.9$ & 64.38 & 35.62 & 64.58 & 35.42 & 75.38 & 24.62 \\
\hline$>25.0$ & 75.41 & 24.59 & 72.06 & 27.94 & 82.91 & 17.09 \\
\hline Breast Feeding & $\chi^{2}=1$ & & $\chi^{2}=1$ & & $\chi^{2}=3$ & \\
\hline $\mathrm{No}^{\oplus}$ & 60.96 & 39.04 & 62.51 & 37.49 & 77.02 & 22.98 \\
\hline Yes & 65.27 & 34.73 & 66.04 & 33.96 & 71.6 & 28.4 \\
\hline Morbidity & $\chi^{2}=1$ & & $\chi^{2}=4$ & & $\chi^{2}=0$ & \\
\hline No Morbidity ${ }^{\circledR}$ & 62.38 & 37.62 & 55.16 & 44.84 & 74.88 & 25.12 \\
\hline Any Morbidity & 63.94 & 36.06 & 65.39 & 34.61 & 74.58 & 25.42 \\
\hline Sex of Child & $\chi^{2}=3$ & & $\chi^{2}=2$ & & $\chi^{2}=3$ & \\
\hline Male $^{\circledR}$ & 61.73 & 38.27 & 63.05 & 36.95 & 73.93 & 26.07 \\
\hline Female & 63.73 & 36.27 & 64.89 & 35.11 & 75.76 & 24.24 \\
\hline Place of Residence & $\chi^{2}=5$ & & $\chi^{2}=5$ & & $\chi^{2}=7$ & \\
\hline Urban & 68.97 & 31.03 & 70.79 & 29.21 & 74.92 & 25.08 \\
\hline Rural & 60.26 & 39.74 & 61.83 & 38.17 & 74.14 & 25.86 \\
\hline Media Exposure & $\chi^{2}=5$ & & $\chi^{2}=1$ & & $\chi^{2}=1$ & \\
\hline No media exposure ${ }^{\oplus}$ & 52.87 & 47.13 & 62.51 & 37.49 & 69.73 & 30.27 \\
\hline Any Media exposure & 64.33 & 35.67 & 66.04 & 33.96 & 75.66 & 24.34 \\
\hline Education of Mother & $\chi^{2}=1$ & & $\chi^{2}=1$ & & $\chi^{2}=1$ & \\
\hline No Education & 49.66 & 50.34 & 54.99 & 45.01 & 73.74 & 26.26 \\
\hline Primary & 50.76 & 49.24 & 53.65 & 46.35 & 68.2 & 31.8 \\
\hline Secondary & 62.85 & 37.15 & 64.38 & 35.62 & 74.38 & 25.62 \\
\hline Higher & 74.36 & 25.64 & 74.77 & 25.23 & 76.28 & 23.72 \\
\hline Religion & $\chi^{2}=3$ & & $\chi^{2}=4$ & & $\chi^{2}=8$ & \\
\hline Hindu & 63.03 & 36.97 & 65.92 & 34.08 & 73.42 & 26.58 \\
\hline Muslim & 69.9 & 30.1 & 68.83 & 31.17 & 77.17 & 22.83 \\
\hline Buddhist & 62.24 & 37.76 & 56.14 & 43.86 & 78.91 & 21.09 \\
\hline Others & 65.4 & 34.6 & 81.06 & 18.94 & 73.18 & 26.82 \\
\hline Caste/Tribe & $\chi^{2}=1$ & & $\chi^{2}=1$ & & $\chi^{2}=3$ & \\
\hline SC & 62.25 & 37.75 & 59.35 & 40.65 & 76.17 & 23.83 \\
\hline ST & 50.14 & 49.86 & 55.55 & 44.45 & 67.57 & 32.43 \\
\hline OBC & 65.4 & 34.6 & 66.94 & 33.06 & 74.84 & 25.16 \\
\hline Others & 68.6 & 31.4 & 71.01 & 28.99 & 75.81 & 24.19 \\
\hline Wealth Index & $\chi^{2}=2$ & & $\chi^{2}=2$ & & $\chi^{2}=4$ & \\
\hline Poorest & 49.83 & 50.17 & 54.96 & 45.04 & 70.62 & 29.38 \\
\hline Poorer & 59.85 & 40.15 & 61.74 & 38.26 & 73.42 & 26.58 \\
\hline Middle & 66.96 & 33.04 & 66.5 & 33.5 & 78 & 22 \\
\hline Richer & 72.62 & 27.38 & 72.84 & 27.16 & 74.05 & 25.95 \\
\hline Richest & 76.09 & 23.91 & 77.39 & 22.61 & 77.28 & 22.72 \\
\hline Region & $\chi^{2}=6$ & & $\chi^{2}=9$ & & $\chi^{2}=4$ & \\
\hline Vidharbha & 61.17 & 38.83 & 61.71 & 38.29 & 73.46 & 26.54 \\
\hline Marathwada & 61.98 & 38.02 & 59.89 & 40.11 & 77.77 & 22.23 \\
\hline North-Maharashtra & 59.92 & 40.08 & 60.47 & 39.53 & 69.55 & 30.45 \\
\hline West-Maharashtra & 72.18 & 27.82 & 76.46 & 23.54 & 77.4 & 22.6 \\
\hline Konkan & 64.88 & 35.12 & 69.26 & 30.74 & 74.23 & 25.77 \\
\hline Total & 64.09 & 35.91 & 65.77 & 34.23 & 74.48 & 25.52 \\
\hline
\end{tabular}


Table 2

Adjusted odd ratio from logistic regressions identifying associations between underweight (weight for age) children and selected background characteristics, NFHS-4.

\begin{tabular}{|c|c|c|c|}
\hline $\begin{array}{l}\text { Background } \\
\text { characteristics }\end{array}$ & Model 1 & Model 2 & Model 3 \\
\hline \multicolumn{4}{|l|}{ Wealth } \\
\hline \multicolumn{4}{|l|}{ Poorest ${ }^{\circledast}$} \\
\hline Poorer & $1.00(0.841 .19)$ & $1.02(0.861 .22)$ & $1.01(0.851 .21)$ \\
\hline Middle & $\begin{array}{l}0.73^{* * *}(0.61 \\
0.87)\end{array}$ & $\begin{array}{l}0.79 * *(0.66 \\
0.95)\end{array}$ & $0.78^{* * *}\left(\begin{array}{lll}0.65 & 0.94\end{array}\right)$ \\
\hline Richer & $\begin{array}{l}0.57 * * *(0.47 \\
0.68)\end{array}$ & $\begin{array}{l}0.67 * * *(0.55 \\
0.82)\end{array}$ & $0.66^{* * *}(0.540 .8)$ \\
\hline Richest & $\begin{array}{l}0.40 * * *(0.32 \\
0.49)\end{array}$ & $\begin{array}{l}0.54 * * *(0.43 \\
0.69)\end{array}$ & $0.53^{* * *}(0.420 .67)$ \\
\hline \multicolumn{4}{|l|}{ Place of Residence } \\
\hline $\begin{array}{l}\text { Rural } \\
\text { Caste/tribe }\end{array}$ & & $0.95(0.841 .08)$ \\
\hline \multicolumn{4}{|l|}{ SC $\mathrm{SC}^{\oplus}$} \\
\hline ST & $\begin{array}{l}1.26^{* *}(1.03 \\
1.53)\end{array}$ & $1.2 *(0.991 .47)$ & $1.21 *(0.991 .48)$ \\
\hline OBC & $0.84 *(0.7 \quad 1)$ & $\begin{array}{l}0.85 *(0.71 \\
1.02)\end{array}$ & $0.85 *(0.71 \quad 1.02)$ \\
\hline Others & $0.87\left(\begin{array}{ll}0.73 & 1.04\end{array}\right)$ & $0.88(0.74 \quad 1.05)$ & $0.87(0.731 .04)$ \\
\hline \multicolumn{4}{|l|}{ Religion } \\
\hline Muslim & $0.85^{* *}(0.731)$ & $\begin{array}{l}0.82 * *(0.7 \\
0.97)\end{array}$ & $0.82^{* *}\left(\begin{array}{ll}0.7 & 0.97\end{array}\right)$ \\
\hline Buddhist & $1.03(0.841 .27)$ & $1.07\left(\begin{array}{lll}0.86 & 1.32\end{array}\right)$ & $1.07(0.861 .32)$ \\
\hline Others & $0.89\left(\begin{array}{lll}0.53 & 1.49)\end{array}\right.$ & $0.89(0.521 .5)$ & $0.87(0.52 \quad 1.47)$ \\
\hline \multicolumn{4}{|l|}{ Regions } \\
\hline Marathwada & $0.94\left(\begin{array}{lll}0.83 & 1.06\end{array}\right)$ & $0.9 *(0.791 .02)$ & $0.9(0.791 .02)$ \\
\hline North Maharashtra & $1.07(0.921 .24)$ & $1.04(0.891 .21)$ & $1.03(0.891 .21)$ \\
\hline West Maharashtra & $\begin{array}{l}0.68 * * *(0.58 \\
0.81)\end{array}$ & $\begin{array}{l}0.69 * * *(0.58 \\
0.82)\end{array}$ & $0.69^{* * *}\left(\begin{array}{ll}0.58 & 0.82\end{array}\right)$ \\
\hline $\begin{array}{l}\text { Konkan } \\
\text { Media Exposure } \\
\text { No media exposure }^{\circledast}\end{array}$ & $0.9\left(\begin{array}{ll}0.76 & 1.06\end{array}\right)$ & $0.89\left(\begin{array}{lll}0.75 & 1.06)\end{array}\right.$ & $0.9\left(\begin{array}{lll}0.76 & 1.07)\end{array}\right.$ \\
\hline $\begin{array}{l}\text { Any Media exposure } \\
\text { Mother's age } \\
<24^{\oplus}\end{array}$ & $0.94\left(\begin{array}{ll}0.81 & 1.08\end{array}\right)$ & $1(0.861 .16)$ & $1(0.861 .16)$ \\
\hline $25-34$ years & & $1.09\left(\begin{array}{ll}0.98 & 1.22\end{array}\right)$ & $1.06(0.951 .18)$ \\
\hline$>34$ years & & $0.98\left(\begin{array}{lll}0.76 & 1.26)\end{array}\right.$ & $0.93(0.721 .2)$ \\
\hline \multicolumn{4}{|l|}{ Mother's Education } \\
\hline \multicolumn{4}{|l|}{ No Education ${ }^{\circledast}$} \\
\hline Primary Education & & $1.18(0.941 .49)$ & $1.18(0.931 .48)$ \\
\hline \multicolumn{3}{|l|}{ Education } & $0.98(0.821 .17)$ \\
\hline Higher Education & & $\begin{array}{l}0.77 * *(0.62 \\
0.94)\end{array}$ & $0.77^{* *}(0.62 \quad 0.94)$ \\
\hline \multicolumn{4}{|l|}{ Child Ever Born } \\
\hline 2 & & $\begin{array}{l}1.12 *(0.99 \\
1.27)\end{array}$ & $1.06(0.941 .2)$ \\
\hline 3 & & $1.09(0.931 .27)$ & $1.04(0.891 .22)$ \\
\hline $4+$ & & $\begin{array}{l}1.57^{* * *}(1.28 \\
1.93)\end{array}$ & $1.52^{* * *}(1.231 .87)$ \\
\hline \multicolumn{4}{|l|}{ BMI } \\
\hline $18.5-24.9$ & & $\begin{array}{l}0.69 * * *(0.62 \\
0.76)\end{array}$ & $0.67^{* * *}\left(\begin{array}{ll}0.61 & 0.75\end{array}\right)$ \\
\hline$>25.0$ & & $\begin{array}{l}0.5^{* * *}(0.42 \\
0.59)\end{array}$ & $0.47^{* * *}(0.4 \quad 0.56)$ \\
\hline
\end{tabular}

ANC

No $\mathrm{ANC}^{\circledast}$

Full ANC

Sex of Child

Male ${ }^{\circledast}$

Female

Child's Age

$<13$ month ${ }^{\oplus}$

13-23 months

Morbidity

No Morbidity ${ }^{\circledast}$

Any Morbidity
Table 2 (continued)

\begin{tabular}{|c|c|c|c|}
\hline $\begin{array}{l}\text { Background } \\
\text { characteristics }\end{array}$ & Model 1 & Model 2 & Model 3 \\
\hline \multicolumn{4}{|l|}{ Breast Feeding } \\
\hline \multicolumn{4}{|l|}{$\mathrm{No}^{\circledast}$} \\
\hline \multirow[t]{2}{*}{ Yes } & & & $0.81 * * *(0.73$ \\
\hline & & & $0.9)$ \\
\hline $\begin{array}{l}\text { Significance level } \\
\text { Dependent } \\
\text { variable }\end{array}$ & \multicolumn{3}{|c|}{$\begin{array}{l}\text { if "P }<0.01=* * *, P<0.05=* *, P<0.1=* " \\
\text { Underweight "No (0), Yes (1)" }\end{array}$} \\
\hline
\end{tabular}

and child background characteristics. In model 2, after adjusting for child characteristics, children are less likely to be wasted with significant result in middle category of wealth index when compared to poorest category. The odds of children to be wasted in Marathwada region is less likely with significant association compared to Vidharbha region in model 2 and model 3 respectively. The odds of children with BMI 18.5-24.9 and 25 an above is less likely to have wasted children as compared to mother with having less than $18.5 \mathrm{BMI}$ in model 2 and model 3 respectively. Women who breastfeed their children are more likely to be wasted.

The detail concentration index by region wise (Table 5) and districts wise is shown in Fig. 3. In addition, the concentration curve is presented in Fig. 4, which describes the concentration index of underweight, wasted and stunted among children in Maharashtra according to their wealth quintiles. It shows that the concentration curve lies above the line of equality, which indicates a disproportionate concentration among the poor.

Table 6 presents results for decomposing the concentration index for nutritional status (underweight, wasted and stunted) inequality. In particular, decomposition analysis shows that the estimated value of the relative contribution to the concentration index was negative in some selected socio-economic factors such place of residence, birth order, mother education, caste, religion, media exposure, children ever born and BMI were the most important contributors explaining the gap in average coefficients of underweight, stunted and wasted children. Place of residence contributed the highest, at $23 \%$ of the gap for underweight and $36 \%$ for stunted, followed by birth order of $13 \%$ for wasted children. Thus, place of residence in Maharashtra was the most determinant contributory factor explaining the gap between rich and poor for both underweight and stunted while birth order was the most contributory factor among wasted children less than 5 years of age. Therefore, it reflected that weaker socio-economic groups in Maharashtra were more disadvantaged in accessing proper nutrition.

\section{Discussion}

Malnutrition has chronically remained a major public health problem among tribal children population in Maharashtra. Nutritional status among children below five years is better in West-Maharashtra than any regions of Maharashtra because all demographic and socioeconomic indicators are better than the other regions of Maharashtra. The study, in general, revealed that malnutrition is an important public health problem where the prevalence of underweight, stunting, and wasting was 38,38 and $28 \%$, respectively. Place of residence, household economic status, woman's employment and woman's age are important determinants of nutrition among women. We found that undernutrition is heavily concentrated among disadvantaged groups, particularly in rural areas and among the ST community, consistent with the previous study. ${ }^{19}$ Percentage of stunted was higher among poorer and middle household wealth quintile, which is similar with other stu$\operatorname{dies}^{20,21,22}$ Socio-economic status like limited access to health services, household food insecurity and the likelihood of poor environmental conditions such as access to clean water, sanitation, and hygiene 
Table 3

Adjusted odd ratio from logistic regressions identifying associations between Stunted (Height for Age) children and selected background characteristics, NFHS-4.

\begin{tabular}{|c|c|c|c|}
\hline $\begin{array}{l}\text { Background } \\
\text { characteristics }\end{array}$ & Model 1 & Model 2 & Model 3 \\
\hline \multicolumn{4}{|l|}{ Wealth } \\
\hline Poorer & $0.97(0.811 .15)$ & $0.99(0.831 .18)$ & $0.98(0.821 .17)$ \\
\hline Middle & $\begin{array}{l}0.83^{* *}(0.7 \\
0.99)\end{array}$ & $0.93(0.771 .11)$ & $0.92(0.771 .1)$ \\
\hline Richer & $\begin{array}{l}0.66 * * *(0.54 \\
0.79)\end{array}$ & $\begin{array}{l}0.79 * *(0.65 \\
0.97)\end{array}$ & $0.78^{* *}(0.64 \quad 0.95)$ \\
\hline Richest & $\begin{array}{l}0.45 * * *(0.37 \\
0.56)\end{array}$ & $\begin{array}{l}0.62 * * *(0.49 \\
0.78)\end{array}$ & $0.61^{* * *}\left(\begin{array}{lll}0.48 & 0.77\end{array}\right)$ \\
\hline \multicolumn{4}{|l|}{ Place of Residence } \\
\hline Rural & $1.1\left(\begin{array}{ll}0.97 & 1.24\end{array}\right)$ & $\begin{array}{l}1.11 *(0.98 \\
1.25)\end{array}$ & $1.11 *(0.98 \quad 1.25)$ \\
\hline $\begin{array}{l}\text { Caste/tribe } \\
\mathrm{SC}^{\oplus}\end{array}$ & & & \\
\hline ST & $0.93(0.761 .13)$ & $0.91(0.741 .1)$ & $0.91(0.751 .11)$ \\
\hline $\mathrm{OBC}$ & $\begin{array}{l}0.71 * * *(0.59 \\
0.85)\end{array}$ & $\begin{array}{l}0.75^{* * *}(0.62 \\
0.9)\end{array}$ & $0.74 * * *\left(\begin{array}{ll}0.62 & 0.89\end{array}\right)$ \\
\hline Others & $\begin{array}{l}0.69 * * *(0.58 \\
0.82)\end{array}$ & $\begin{array}{l}0.71 * * *(0.59 \\
0.84)\end{array}$ & $0.7^{* * *}(0.59 \quad 0.83)$ \\
\hline \multicolumn{4}{|l|}{ Religion } \\
\hline Muslim & $1.09(0.941 .27)$ & $1.02(0.88$ 1.19) & $1.01(0.861 .18)$ \\
\hline Buddhist & 1.17 (0.95 1.44) & $\begin{array}{l}1.24 * *(1.01 \\
1.53)\end{array}$ & $1.24^{* *}(1.01 \quad 1.54)$ \\
\hline $\begin{array}{l}\text { Others } \\
\text { Regions } \\
\text { Vidharbha }^{\circledast}\end{array}$ & $0.74\left(\begin{array}{lll}0.43 & 1.3\end{array}\right)$ & $0.77(0.44 \quad 1.35)$ & $0.76\left(\begin{array}{lll}0.43 & 1.32\end{array}\right)$ \\
\hline Marathwada & $1.09(0.961 .23)$ & $1.02\left(\begin{array}{ll}0.9 & 1.16\end{array}\right)$ & $1.02\left(\begin{array}{ll}0.9 & 1.16\end{array}\right)$ \\
\hline North Maharashtra & $1.07(0.921 .24)$ & $1.01(0.871 .18)$ & $1(0.861 .17)$ \\
\hline West Maharashtra & $\begin{array}{l}0.62^{* * *}(0.52 \\
0.74)\end{array}$ & $\begin{array}{l}0.60 * * *(0.5 \\
0.71)\end{array}$ & $0.59 * * *(0.5 \quad 0.71)$ \\
\hline Konkan & $0.88(0.741 .04)$ & $\begin{array}{l}0.86 *(0.73 \\
1.02)\end{array}$ & $0.86 *(0.731 .02)$ \\
\hline \multicolumn{4}{|l|}{ Media Exposure } \\
\hline $\begin{array}{l}\text { Any Media exposure } \\
\text { Mother's age } \\
<24^{\oplus}\end{array}$ & $0.93\left(\begin{array}{ll}0.8 & 1.08\end{array}\right)$ & $1(0.861 .16)$ & $1.01(0.871 .18)$ \\
\hline $\begin{array}{l}25-34 \text { years } \\
>34 \text { years }\end{array}$ & & $0.98(0.881 .09)$ & $0.96(0.871 .07)$ \\
\hline \multicolumn{4}{|l|}{ Mother's Education } \\
\hline Primary Education & & $1.11(0.881 .4)$ & $1.1(0.871 .38)$ \\
\hline $\begin{array}{l}\text { Secondary } \\
\text { Education }\end{array}$ & & $0.87\left(\begin{array}{ll}0.73 & 1.04\end{array}\right)$ & $0.86 *(0.721 .03)$ \\
\hline Higher Education & & $\begin{array}{l}0.66 * * *(0.54 \\
0.81)\end{array}$ & $0.65^{* * *}\left(\begin{array}{ll}0.53 & 0.81\end{array}\right)$ \\
\hline \multicolumn{4}{|l|}{$1^{\oplus}$} \\
\hline 2 & & $1.04(0.921 .17)$ & $1.02\left(\begin{array}{ll}0.9 & 1.15\end{array}\right)$ \\
\hline 3 & & $1.08(0.921 .26)$ & $1.05(0.91 .23)$ \\
\hline $4+$ & & $\begin{array}{l}1.41 * * *(1.15 \\
1.73)\end{array}$ & $1.39 * * *(1.131 .71)$ \\
\hline \multicolumn{4}{|l|}{ BMI } \\
\hline $18.5-24.9$ & & $\begin{array}{l}0.85 * * *(0.77 \\
0.95)\end{array}$ & $0.85^{* * *}\left(\begin{array}{ll}0.76 & 0.95\end{array}\right)$ \\
\hline$>25.0$ & & $\begin{array}{l}0.76^{* * *}(0.65 \\
0.9)\end{array}$ & $0.75^{* * *}\left(\begin{array}{ll}0.63 & 0.88\end{array}\right)$ \\
\hline \multicolumn{4}{|l|}{ ANC } \\
\hline $\begin{array}{l}\text { Full ANC } \\
\text { Sex of Child } \\
\text { Male }^{\circledR}\end{array}$ & & $0.93(0.841 .03)$ & $0.96(0.861 .06)$ \\
\hline Female & & & $\left.0.88^{* *(0.8} \quad 0.97\right)$ \\
\hline \multicolumn{4}{|l|}{ Child's Age } \\
\hline $\begin{array}{l}13-23 \text { months } \\
\text { Morbidity } \\
\text { No Morbidity }\end{array}$ & & & $1.34^{* * *}(1.18 \quad 1.52)$ \\
\hline
\end{tabular}

Table 3 (continued)

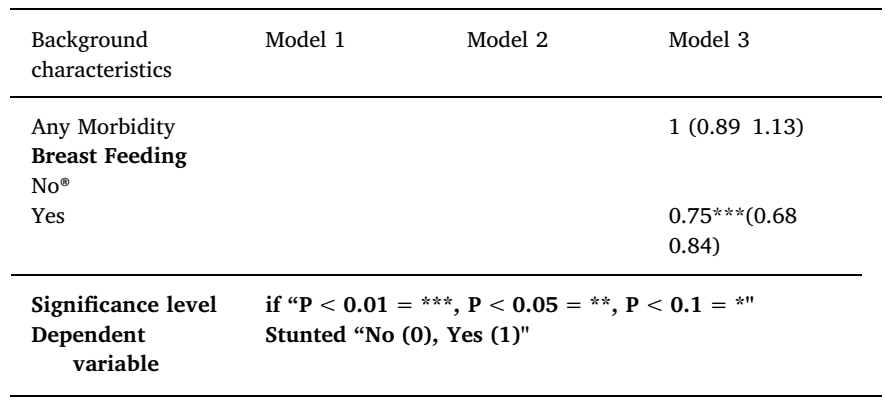

increase the likelihood of illness. ${ }^{20,23}$ Women of low economic status have the highest prevalence of under-nutrition, which may be due to food insecurity in these households that negatively impacts the nutritional status of women. It was also observed that educational status of the mother positively affected the nutritional status of children. Educated mothers are more aware of their child's health and have a superior shot of utilizing the health services as compared to the illiterate ones. This study, also revealed that underweight was significantly higher among children whose mothers were illiterate compared with children whose mothers had secondary and higher education, which are similar with the findings reported by Meshram et al. ${ }^{22,24}$ Mothers' education level was associated with progressively effective management of limited household resources, lower fertility, improved healthpromoting behaviour, better utilization of health-care services, and more child-centered caring practices ${ }^{21,25}$

Mothers BMI also emerged as a major predictor of underweight and stunted children, showing that both maternal and child under-nutrition are interrelated. Program implementers and policy-makers should act simultaneously and design new ways to deal with these interrelations while into account while designing child nutrition program including their life-cycle and intergenerational effects. ${ }^{26}$ Morbidities (such as fever, diarrhoea, and ARIs) were significantly associated with underweight, stunted and wasted indicating that morbidity plays a significant role in determining under-nutrition among children in Maharashtra, reported in the previous study also. ${ }^{22}$ Undernourished mothers and low birth weight women during pregnancy cannot breast-feed their children sufficiently ${ }^{27,28,9}$ Hence, initiation of complementary feeding and quality of the complementary food could help to the reduction of malnutrition among children ${ }^{29,30}$

\section{Conclusion}

The aim of this paper was to explore the geographical variations in malnutrition in Maharashtra. The present study plentifully uncovers that, as far as child nutrition is concerned, the Scheduled Tribes groups seems to be socially excluded among all the social classes. Economic growth has played a definite role in reducing child nutrition, but it is not primarily responsible for the significant decline. As per the results, we have seen that among rich and poor inequalities exists and were highly significantly different regions of Maharashtra.

Despite significant progress in the reduction of infant mortality rate (IMR) and maternal mortality rate (MMR) with significant economic growth also. Few efforts have been made through Comprehensive Nutrition Survey Maharashtra (CNSM) conducted in 2011-12 and Rajmata Jijau Mother-Child Health and Nutrition mission whose aim was to reduce child under-nutrition under two years, they seem to have done precisely. Maharashtra has not been able to make significant progress in improving the nutritional status of the population. It can also easily be reflected by Hunger index that compared to other states of the country which are not economically well, Hunger index rank of Maharashtra is poor. Thus, the situation of malnutrition is a major public health problem in India as well as in Maharashtra, and we need 
Table 4

Adjusted odd ratio from logistic regressions identifying associations between wasted (weight for height) children and selected background characteristics, NFHS-4.

\begin{tabular}{|c|c|c|c|}
\hline $\begin{array}{l}\text { Background } \\
\text { characteristics }\end{array}$ & Model 1 & Model 2 & Model 3 \\
\hline \multicolumn{4}{|l|}{ Wealth } \\
\hline \multicolumn{4}{|l|}{ Poorest $^{\circledast}$} \\
\hline Poorer & $0.91\left(\begin{array}{lll}0.76 & 1.1)\end{array}\right.$ & $0.9\left(\begin{array}{lll}0.74 & 1.09\end{array}\right)$ & $0.9(0.741 .09)$ \\
\hline Middle & $\begin{array}{l}0.79 * *(0.66 \\
0.96)\end{array}$ & $\begin{array}{l}0.79 * *(0.65 \\
0.97)\end{array}$ & $0.79 * *(0.650 .97)$ \\
\hline Richer & $\begin{array}{l}0.75^{* * * *}(0.61 \\
0.92)\end{array}$ & $\begin{array}{l}0.77 * *(0.62 \\
0.95)\end{array}$ & $0.77^{* *}(0.620 .96)$ \\
\hline Richest & $\begin{array}{l}0.65^{* * * *}(0.52 \\
0.82)\end{array}$ & $\begin{array}{l}0.69 * * *(0.54 \\
0.89)\end{array}$ & $\left.0.7^{* * *(0.54} \quad 0.9\right)$ \\
\hline \multicolumn{4}{|l|}{ Place of Residence } \\
\hline $\begin{array}{l}\text { Rural } \\
\text { Caste/tribe } \\
\text { SC }^{\oplus}\end{array}$ & 0.97 (0.85 1.1) & $0.93\left(\begin{array}{lll}0.82 & 1.06)\end{array}\right.$ & $0.92(0.81 \quad 1.06)$ \\
\hline ST & $1.17(0.941 .46)$ & $1.16(0.931 .44)$ & $1.16(0.931 .44)$ \\
\hline OBC & $1(0.821 .23)$ & $1(0.821 .22)$ & $1.01(0.831 .24)$ \\
\hline Others & $1.02\left(\begin{array}{ll}0.84 & 1.24\end{array}\right)$ & $1.02\left(\begin{array}{ll}0.84 & 1.24\end{array}\right)$ & $1.03(0.851 .26)$ \\
\hline \multicolumn{4}{|l|}{ Religion } \\
\hline \multicolumn{4}{|l|}{ Hindu $^{\oplus}$} \\
\hline Muslim & $0.88\left(\begin{array}{lll}0.74 & 1.04)\end{array}\right.$ & $0.91(0.761 .08)$ & $0.9\left(\begin{array}{ll}0.76 & 1.08\end{array}\right)$ \\
\hline Buddhist & $0.93\left(\begin{array}{ll}0.73 & 1.18\end{array}\right)$ & $0.93\left(\begin{array}{ll}0.73 & 1.19\end{array}\right)$ & $0.94\left(\begin{array}{lll}0.74 & 1.2\end{array}\right)$ \\
\hline Others & $1.22\left(\begin{array}{ll}0.73 & 2.04\end{array}\right)$ & $1.24\left(\begin{array}{ll}0.73 & 2.1)\end{array}\right.$ & $1.24(0.732 .1)$ \\
\hline \multicolumn{4}{|l|}{ Regions } \\
\hline \multicolumn{4}{|l|}{ Vidharbha ${ }^{\circledast}$} \\
\hline Marathwada & $\begin{array}{l}0.77^{* * *}(0.67 \\
0.88)\end{array}$ & $\begin{array}{l}0.77 * * *(0.67 \\
0.89)\end{array}$ & $0.77^{* * *}\left(\begin{array}{ll}0.67 & 0.89\end{array}\right)$ \\
\hline North Maharashtra & $1.12(0.961 .31)$ & $1.14(0.971 .34)$ & \multirow{2}{*}{$\begin{array}{l}1.14\left(\begin{array}{ll}0.97 & 1.34\end{array}\right) \\
0.79 * *\left(\begin{array}{ll}0.65 & 0.95\end{array}\right)\end{array}$} \\
\hline West Maharashtra & $\begin{array}{l}0.76^{* * *}(0.64 \\
0.91)\end{array}$ & $\begin{array}{l}0.79 * *(0.66 \\
0.95)\end{array}$ & \\
\hline $\begin{array}{l}\text { Konkan } \\
\text { Media Exposure } \\
\text { No media exposure }\end{array}$ & $0.93(0.781 .11)$ & $0.95(0.791 .14)$ & $0.94(0.78$ 1.13) \\
\hline $\begin{array}{l}\text { Any Media exposure } \\
\text { Mother's age } \\
<24^{\oplus}\end{array}$ & 0.9 (0.76 1.05) & $0.89\left(\begin{array}{lll}0.76 & 1.05\end{array}\right)$ & $0.89(0.751 .04)$ \\
\hline $25-34$ years & & $1.04(0.931 .17)$ & 1.06 (0.95 1.19) \\
\hline$>34$ years & & $1.18(0.91 .54)$ & $1.21(0.921 .58)$ \\
\hline $\begin{array}{l}\text { Mother's Education } \\
\text { No Education }\end{array}$ & & & \\
\hline Primary Education & & $1.23(0.951 .58)$ & $1.24(0.961 .59)$ \\
\hline $\begin{array}{l}\text { Secondary } \\
\text { Education }\end{array}$ & & $1.14(0.941 .38)$ & 1.15 (0.95 1.4) \\
\hline Higher Education & & $1.11\left(\begin{array}{ll}0.88 & 1.39\end{array}\right)$ & $1.12(0.891 .41)$ \\
\hline $\begin{array}{l}\text { Child Ever Born } \\
1^{\oplus}\end{array}$ & & & \\
\hline 2 & & $0.95(0.831 .08)$ & $0.99(0.87$ 1.13) \\
\hline 3 & & $0.92\left(\begin{array}{ll}0.78 & 1.09\end{array}\right)$ & $0.96(0.811 .14)$ \\
\hline $4+$ & & $1.07(0.851 .33)$ & $1.12(0.891 .4)$ \\
\hline $\begin{array}{l}\text { BMI } \\
<18.5^{\oplus}\end{array}$ & & & \\
\hline $18.5-24.9$ & & $\begin{array}{l}0.79 * * *(0.71 \\
0.89)\end{array}$ & $0.8^{* * *}(0.71 \quad 0.9)$ \\
\hline$>25.0$ & & $\begin{array}{l}0.53^{* * * *}(0.44 \\
0.64)\end{array}$ & $0.54 * * *\left(\begin{array}{ll}0.45 & 0.65\end{array}\right)$ \\
\hline $\begin{array}{l}\text { ANC } \\
\text { No ANC }{ }^{\circledast}\end{array}$ & & & \\
\hline $\begin{array}{l}\text { Full ANC } \\
\text { Sex of Child } \\
\text { Male }^{\circledR}\end{array}$ & & $1.05(0.941 .18)$ & 1.01 (0.9 1.13) \\
\hline Female & & & $0.9 * *(0.81 \quad 0.99)$ \\
\hline $\begin{array}{l}\text { Child's Age } \\
<13 \text { month }^{\oplus}\end{array}$ & & & \\
\hline 13-23 months & & & $0.89 *(0.77 \quad 1.02)$ \\
\hline Morbidity & & & \\
\hline No Morbidity ${ }^{\circledast}$ & & & \\
\hline Any Morbidity & & & $1.01(0.891 .15)$ \\
\hline Breast Feeding & & & \\
\hline $\mathrm{No}^{\circledast}$ & & & \\
\hline Yes & & & $\begin{array}{l}1.32 * * *(1.18 \\
1.48)\end{array}$ \\
\hline
\end{tabular}

Table 4 (continued)

\begin{tabular}{|c|c|c|}
\hline $\begin{array}{l}\text { Background } \\
\text { characteristics }\end{array}$ & Model 2 & Model 3 \\
\hline $\begin{array}{l}\text { Significance level } \\
\text { Dependent } \\
\text { variable }\end{array}$ & \multicolumn{2}{|c|}{$\begin{array}{l}\text { if "P }<0.01=* * *, P<0.05=* *, P<0.1=* " \\
\text { Wasted "No (0), Yes (1)" }\end{array}$} \\
\hline
\end{tabular}

to train our grass root level workers especially the Anganwadi workers to screen the children nutritionally. In addition, it is important to understand on what aspects of the mission contributed to the decline in child under-nutrition, why the decline was confined largely to children belonging to two or three age groups and why the interventions helped reduce stunting the most, but not wasting and underweight. Therefore, it is essential to have better coordination with huge resources, both in terms of human and financial, which are in short supply, due to which the zeal of any mission is likely to dissipate.

\section{Recommendations}

Any mission running in the long run, should integrate itself with the public health system and strengthens to ensure that the gains and momentum achieved so far are not lost. Proper support in terms of knowledge regarding child feeding practices, identification of risk of malnutritiion, etc., the Anganwadi workers at grass root level need to be trained to screen the children nutritionally. Therefore, there is a need to strengthen all the present nutrition intervention programmes such as Integrated Child Development Scheme (ICDS), Anthyodaya Anna Yojana Scheme, etc., to improve the nutritional status of the community. Campaigns need to be conducted to enhance female literacy, promote appropriate weaning practices, and awareness about dietary and nutritional values, particularly among the tribal population. National Health Mission (NHM) and National Nutrition Mission (NNM) an initiative by Govt. of India are working to improve child and maternal health across India. The district level inequalities would be helpful to the planners and policymakers to help build new intervention for those specific underprivileged districts ${ }^{31,32}$

\section{Author contributions}

Conceived and designed the research paper: RK, and HC; analysed the data: RK, HC; Contributed agents/materials/analysis tools: RK, HC; Wrote the manuscript: RK, HC, Refined the manuscript: HC, and RK.

\section{Compliance with ethical standards}

\section{Conflict of interest}

The authors declare no conflict of interest.

\section{Informed consent}

Informed consent was obtained from all individual participants included in the study.

\section{Ethical treatment of experimental subjects (animal and human)}

Disclosure of potential conflicts of interest has been provided. This study was based on a large dataset that is publicly available on population ageing in India conducted by the UNFPA in India with ethical standards being complied with including informed consent obtained from participants. This research received no grant from any funding agency in the public, commercial or not-for-profit sectors. 
Table 5

Concentration Index values for underweight, stunted and wasted across different regions of Maharashtra, India, NFHS-4.

\begin{tabular}{|c|c|c|c|c|c|c|}
\hline & Vidharbha & Marathwada & North Maharashtra & West Maharashtra & Kokan & Maharashtra \\
\hline Underweight & -0.128 & -0.097 & -0.145 & -0.140 & -0.160 & -0.136 \\
\hline Stunted & -0.114 & -0.077 & -0.132 & -0.141 & -0.125 & -0.123 \\
\hline Wasted & -0.075 & -0.065 & -0.068 & -0.066 & -0.050 & -0.071 \\
\hline
\end{tabular}

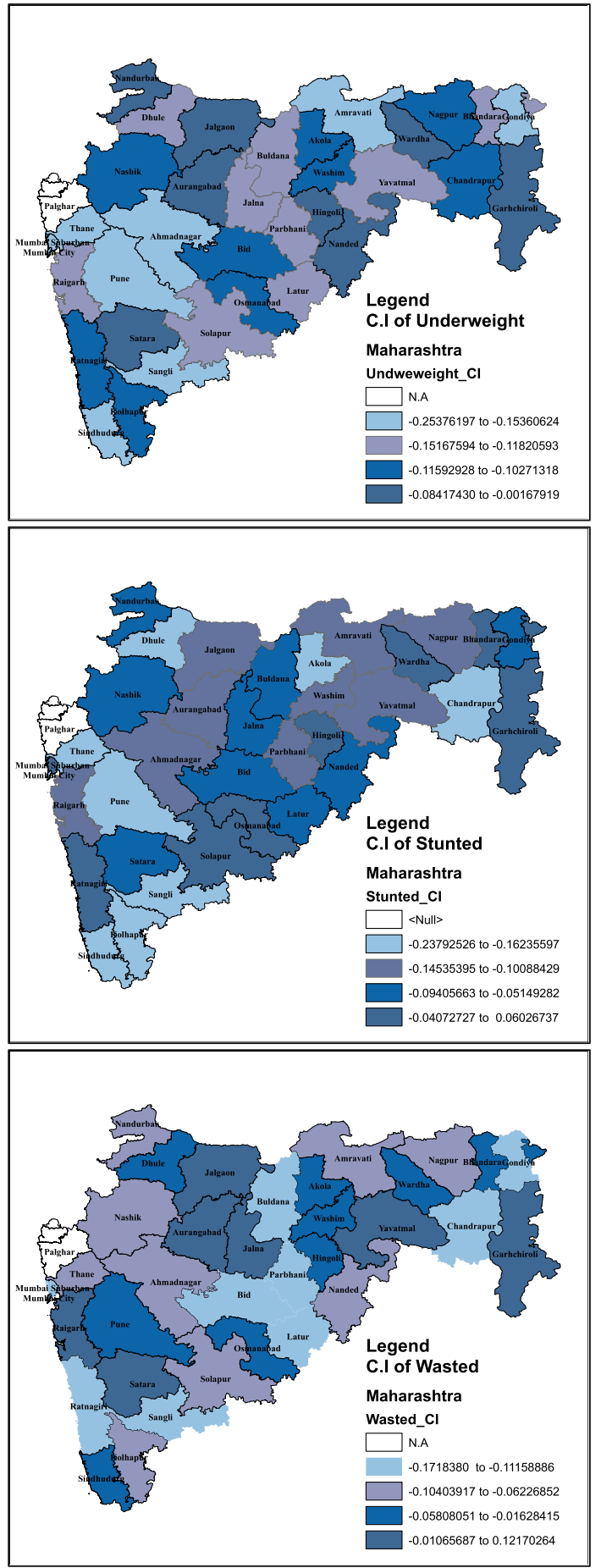

Fig. 3. Districts wise Concentration Index Values for underweight, stunted and wasted in Maharashtra, India, NFHS-4.
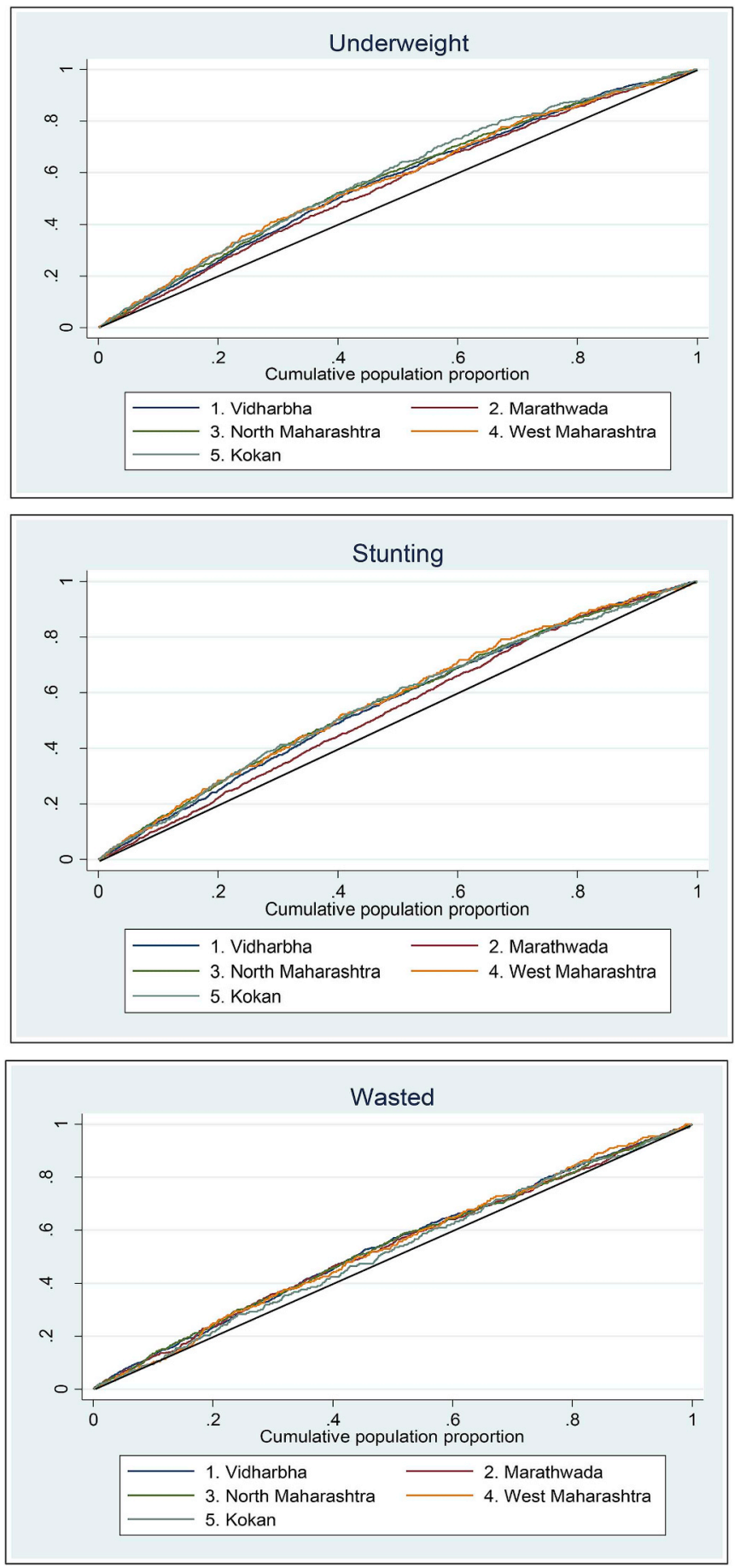

Fig. 4. Region wise Concentration curve of Underweight, stunted and wasted in Maharashtra, India, NFHS-4. 
Table 6

Contribution of each factor in poor \& non-poor differentials in underweight and stunted children in Maharashtra, India, NFHS-4.

\begin{tabular}{|c|c|c|c|c|c|c|c|c|c|c|c|c|}
\hline & \multicolumn{4}{|c|}{ Underweight } & \multicolumn{4}{|l|}{ Stunted } & \multicolumn{4}{|l|}{ Wasted } \\
\hline & Elasticity & $\mathrm{CI}$ & Absolute & $\%$ & Elasticity & $\mathrm{CI}$ & Absolute & $\%$ & Elasticity & CI & Absolute & $\%$ \\
\hline Place of Residence & 0.0574 & -0.0808 & -0.0185 & 22.9495 & 0.0912 & -0.0808 & -0.0295 & 36.4699 & -0.032 & -0.0808 & 0.0103 & -12.8097 \\
\hline Birth Order & -0.0519 & -0.0243 & 0.0051 & -20.7662 & -0.0278 & -0.0243 & 0.0027 & -11.1332 & 0.0322 & -0.0243 & -0.0031 & 12.8917 \\
\hline Mother Education & -0.1173 & 0.1287 & -0.0604 & -46.9232 & -0.1015 & 0.1287 & -0.0523 & -40.5849 & 0.0043 & 0.1287 & 0.0022 & 1.7004 \\
\hline Caste & -0.0814 & 0.0424 & -0.0138 & -32.5437 & -0.1093 & 0.0424 & -0.0185 & -43.7004 & -0.0246 & 0.0424 & -0.0042 & -9.8528 \\
\hline Religion & -0.0275 & 0.0088 & -0.001 & -11.0167 & 0.0141 & 0.0088 & 0.0005 & 5.6495 & -0.0394 & 0.0088 & -0.0014 & -15.7421 \\
\hline Media & -0.0187 & 0.1147 & -0.0086 & -7.483 & -0.0207 & 0.1147 & -0.0095 & -8.2952 & -0.0165 & 0.1147 & -0.0076 & -6.6093 \\
\hline Children Ever Born & 0.0873 & -0.0619 & -0.0216 & 34.9038 & 0.0566 & -0.0619 & -0.014 & 22.6437 & -0.0109 & -0.0619 & 0.0027 & -4.3682 \\
\hline BMI & -0.1557 & 0.0521 & -0.0325 & -62.2679 & -0.0676 & 0.0521 & -0.0141 & $\mathrm{~V}$ & -0.1086 & 0.0521 & -0.0227 & -43.4367 \\
\hline
\end{tabular}

\section{Appendix A. Supplementary data}

Supplementary data to this article can be found online at https://doi.org/10.1016/j.cegh.2019.05.008.

\section{Appendix}

Table A

Districts wise prevalence and its rank (Highest to Lowest) of Underweight, stunted and wasted in Maharashtra, India, NFHS-4

\begin{tabular}{|c|c|c|c|c|c|c|c|}
\hline \multirow[t]{2}{*}{ Region } & \multirow[t]{2}{*}{ Districts } & \multicolumn{2}{|l|}{ Underweight } & \multicolumn{2}{|l|}{ Stunted } & \multicolumn{2}{|l|}{ Wasted } \\
\hline & & Prevalence & Rank & Prevalence & Rank & Prevalence & Rank \\
\hline \multirow[t]{11}{*}{ Vidharbha } & Akola & 39.49 & 15 & 39.87 & 11 & 23.16 & 21 \\
\hline & Amravati & 32.34 & 25 & 39.04 & 12 & 23.14 & 22 \\
\hline & Bhandara & 32.02 & 26 & 40.55 & 9 & 15.53 & 35 \\
\hline & Buldana & 41.73 & 10 & 44.03 & 4 & 21.51 & 27 \\
\hline & Chandrapur & 40.3 & 13 & 32.66 & 23 & 31.15 & 6 \\
\hline & Gadchiroli & 42.69 & 8 & 32.24 & 24 & 46.59 & 1 \\
\hline & Gondiya & 40.99 & 11 & 35.14 & 19 & 29.95 & 8 \\
\hline & Nagpur & 33.46 & 24 & 33.77 & 22 & 25.89 & 13 \\
\hline & Wardha & 35.88 & 18 & 30.50 & 26 & 25.66 & 14 \\
\hline & Washim & 43.04 & 7 & 40.35 & 10 & 32.44 & 5 \\
\hline & Yavatmal & 48.00 & 2 & 46.14 & 3 & 29.41 & 10 \\
\hline \multirow[t]{5}{*}{ North-Maharashtra } & Ahmadnagar & 31.26 & 27 & 34.53 & 21 & 21.29 & 28 \\
\hline & Dhule & 46.77 & 3 & 38.16 & 16 & 31.07 & 7 \\
\hline & Jalgaon & 35.45 & 20 & 35.52 & 18 & 32.97 & 3 \\
\hline & Nandurbar & 56.17 & 1 & 47.38 & 1 & 39.34 & 2 \\
\hline & Nashik & 42.43 & 9 & 42.75 & 6 & 32.73 & 4 \\
\hline \multirow[t]{5}{*}{ West-Maharashtra } & Kolhapur & 30.96 & 28 & 26.32 & 29 & 24.51 & 16 \\
\hline & Pune & 24.86 & 33 & 21.64 & 34 & 23.60 & 18 \\
\hline & Sangli & 24.50 & 34 & 23.22 & 32 & 16.61 & 34 \\
\hline & Satara & 26.83 & 31 & 22 & 33 & 22.59 & 24 \\
\hline & Solapur & 33.86 & 23 & 26.35 & 28 & 23.28 & 20 \\
\hline \multirow[t]{6}{*}{ Konkan } & Mumbai & 23.78 & 35 & 25.9 & 31 & 25.14 & 15 \\
\hline & Mumbai Suburban & 29.80 & 30 & 21.37 & 35 & 20.45 & 30 \\
\hline & Raigarh & 39.53 & 14 & 31.47 & 25 & 29.61 & 9 \\
\hline & Ratnagiri & 30.49 & 29 & 28.12 & 27 & 23.57 & 19 \\
\hline & Sindhudurg & 26.26 & 32 & 26.01 & 30 & 20.42 & 31 \\
\hline & Thane & 40.90 & 12 & 39.03 & 13 & 29.24 & 11 \\
\hline \multirow[t]{8}{*}{ Marathwada } & Aurangabad & 35.85 & 19 & 38.22 & 15 & 20.86 & 29 \\
\hline & Beed & 37.04 & 16 & 37.95 & 17 & 28.51 & 12 \\
\hline & Hingoli & 36.69 & 17 & 38.73 & 14 & 23.86 & 17 \\
\hline & Jalna & 43.45 & 5 & 43.65 & 5 & 22.21 & 25 \\
\hline & Latur & 34.87 & 22 & 34.59 & 20 & 22.77 & 23 \\
\hline & Nanded & 34.96 & 21 & 40.86 & 8 & 20.19 & 32 \\
\hline & Osmanabad & 45.30 & 4 & 42.41 & 7 & 21.60 & 26 \\
\hline & Parbhani & 43.04 & 6 & 46.73 & 2 & 20.19 & 33 \\
\hline
\end{tabular}

\section{References}

1. De Onis M, Blössner M, Borghi E, Frongillo EA, Morris R. Estimates of global prevalence of childhood underweight in 1990 and 2015. Jama. 2004;291(21):2600-2606.

2. De Onis M, Brown D, Blossner M, Borghi E. Levels and Trends in Child Malnutrition. UNICEF-WHO-The World Bank Joint Child Malnutrition Estimates. 2012; 2012

3. Nutrition IC. The Achievable Imperative for Global Progress New York. New York, NY, USA: NY United Nations Children's Fund; 2013.

4. UNICEF. Malnutrition in children. Available at: https://data.unicef.org/topic/ nutrition/malnutrition/; 2018.

5. Rammohan M, Kalantar-Zadeh K, Liang A, Ghossein C. Megestrol acetate in a moderate dose for the treatment of malnutrition-inflammation complex in maintenance dialysis patients. J Ren Nutr. 2005;15(3):345-355.

6. Rathaur VK, Pathania M, Pannu C, et al. Prevalent infant feeding practices among the mothers presenting at a tertiary care hospital in Garhwal Himalayan region, Uttarakhand, India. J Fam Med Prim Care. 2018;7(1):45.

7. Chaudhary SR, Govil S, Lala MK, Yagnik HB. Infant and young child feeding index and its association with nutritional status: a cross-sectional study of urban slums of Ahmedabad. J Family Commun Med. 2018;25(2):88.

8. Black RE, Morris SS, Bryce J. Where and why are 10 million children dying every 
year? The lancet. 2003;361(9376):2226-2234

9. Black RE, Victora CG, Walker SP, et al. Maternal and child undernutrition and overweight in low-income and middle-income countries. The lancet. 2013;382(9890):427-451.

10. Kamath SM, Venkatappa KG, Sparshadeep EM. Impact of nutritional status on cognition in institutionalized orphans: a pilot study. J Clin Diagn Res: J Clin Diagn Res. 2017;11(3):CC01

11. Chauhan BG, Chauhan S, Chaurasia H. Decomposing the gap in child malnutrition between poor and non-poor in Sierra Leone. J Public Health. 2018:1-9.

12. Kumar A, Singh A. Decomposing the gap in childhood undernutrition between poor and non-poor in urban India, 2005-06. PLoS One. 2013;8(5):e64972.

13. Microdata World Bank. National family health survey 4 (NFHS 4). http://microdata. worldbank.org/index.php/catalog/2949/sampling; 2018.

14. Szabo S, Hajra R, Baschieri A, Matthews Z. Inequalities in human well-being in the urban ganges brahmaputra meghna delta. Sustainability. 2016;8(7):608https://doi. org $/ 10.3390 /$ su8070608.

15. Wagstaff A, Paci P, Van Doorslaer E. On the measurement of inequalities in health. Soc Sci Med. 1991;33(5):545-557https://doi.org/10.1016/0277-9536(91)90212-U.

16. Kakwani N, Wagstaff A, Van Doorslaer E. Socioeconomic inequalities in health: measurement, computation, and statistical inference. J Econom. 1997;87:103https:// doi.org/10.1016/S0304-4076(96)01807-6.

17. Van Doorslaer E, Koolman X. Explaining the differences in income-related health inequalities across European countries. Health Econ. 2004;13(7):609-628https://doi. org/10.1002/hec.918.

18. Hosseinpoor AR, Van Doorslaer E, Speybroeck N, et al. Decomposing socioeconomic inequality in infant mortality in Iran. Int J Epidemiol. 2006;35(5):1211-1219https:// doi.org/10.1093/ije/dyl164.

19. Joe W, Mishra US, Navaneetham K. Inter-group inequalities in child undernutrition in India: group Analogue of the gini coefficient and atkinson's index. Oxf Dev Stud. 2013;41(2):239-257.

20. El-Sayed N, Mohamed AG, Nofal L, Mahfouz A, Zeid HA. Malnutrition among preschool children in Alexandria, Egypt. J Health Popul Nutr. 2001:275-280.

21. Shah SM, Selwyn BJ, Luby S, Merchant A, Bano R. Prevalence and correlates of stunting among children in rural Pakistan. Pediatr Int. 2003;45(1):49-53.

22. Meshram II, Arlappa N, Balakrishna N, et al. Prevalence and determinants of undernutrition and its trends among pre-school tribal children of Maharashtra State, India. J Trop Pediatr. 2011;58(2):125-132.
23. Daniels DL, Cousens SN, Makoae LN, Feachem RG. A case-control study of the impact of improved sanitation on diarrhoea morbidity in Lesotho. Bull World Health Organ 1990;68(4):455

24. Meshram II, Laxmaiah A, Gal Reddy CH, Ravindranath M, Venkaiah K, Brahmam GNV. Prevalence of under-nutrition and its correlates among under 3 year-old children in rural areas of Andhra Pradesh, India. Ann Hum Biol. 2011;38(1):93-101.

25. Hien NN, Kam S. Nutritional status and the characteristics related to malnutrition in children under five years of age in Nghean, Vietnam. J Prevent Med Pub Health. 2008;41(4):232-240.

26. Abu-Saad K, Fraser D. Maternal nutrition and birth outcomes. Epidemiol Rev. 2010;32(1):5-25.

27. Rahman A, Chowdhury S. Determinants of chronic malnutrition among preschool children in Bangladesh. J Biosoc Sci. 2007;39(2):161-173.

28. Rahman M, Roy SK, Ali M, Mitra AK, Alam AN, Akbar MS. Maternal nutritional status as a determinant of child health. J Trop Pediatr. 1993;39(2):86-88.

29. Zhou H, Wang XL, Ye F, Zeng LXP, Wang Y. Relationship between child feeding practices and malnutrition in 7 remote and poor counties, PR China. Asia Pac J Clin Nutr. 2012;21(2):234-240.

30. Tiwari R, Ausman LM, Agho KE. Determinants of stunting and severe stunting among under-fives: evidence from the 2011 Nepal Demographic and Health Survey. BMC Pediatr. 2014;14(1):239.

31. Murray SF, Hunter BM, Bisht R, Ensor T, Bick D. Effects of demand-side financing on utilisation, experiences and outcomes of maternity care in low-and middle-income countries: a systematic review. BMC Pregnancy Childbirth. 2014;14(1):30.

32. Falcao VL, Khanuja J, Matharu S, Nehra S, Sinha D. Report on the Study of the Indira Gandhi Matritva Sahyog Yojana. New Delhi: Centre for Equity Studies; 2015.

Mr. Rushikesh P Khadse is an M.Phil. Scholar of International Institute for Population Sciences, Mumbai-400088. His research interests include ageing issues, maternal and child health, reproductive and child health, fertility, and gender.

Mr. Himanshu Chaurasia is working as Scientist-B (Statistician) at National Institute for Research in Reproductive Health, ICMR, Parel, Mumbai. His research interests include population and development; ageing issues and health; fertility; public health and mortality; maternal and child health, reproductive and child health, migration and urbanization. 